\title{
REVIEWS
}

\section{UNDERSTANDING THE IMPLICATIONS OF SPATIAL SEGREGATION IN BELFAST, NORTHERN IRELAND}

\author{
AUTHORS \\ Peter Kumer \\ Research Centre of the Slovenian Academy of Sciences and Arts, Anton Melik Geographical Institute, Gosposka \\ ulica 13, SI - 1000 Ljubljana, Slovenia \\ peter.kumer@zrc-sazu.si

\section{dr. Marko Krevs} \\ University of Ljubljana, Faculty of Arts, Department of Geography, Aškerčeva 2, SI - 1000 Ljubljana, Slovenia \\ marko.krevs@ff.uni-lj.si
}

DOI: $10.3986 / G V 87204$

UDC: 911.3: 37.014.511:2(410.7Belfast)

COBISS: 1.01

\section{ABSTRACT}

\section{Understanding the implications of spatial segregation in Belfast, Northern Ireland}

The conflict in Belfast that revolves around identity and territory has strong spatial implications. This paper seeks to identify the drivers that promote spatial segregation within the city. The drivers are identified through recent research based on semi-structural interviews with members of the Catholic and Protestant communities, in-depth interviews with decision-makers, and a cartographic analysis of the contested areas. This study aims to provide recommendations to support the spatial integration of both communities and their reconciliation process.

\section{KEY WORDS}

political geography, spatial segregation, territoriality, interface community, cross community, reconciliation, Belfast, Northern Ireland

\section{IZVLEČEK}

\section{Razumevanje posledic prostorske segregacije $v$ Belfastu na Severnem Irskem}

Belfastski konflikt, ki je povezan z identiteto in teritorijem, pušča pomembne posledice v prostoru. Prispevek obravnava dejavnike (gonilne sile), ki spodbujajo prostorsko segregacijo v mestu. Dejavniki so bili prepoznani na podlagi polstrukturiranih intervjujev, opravljenih s predstavniki katoliške in protestantske skupnosti, poglobljenih intervjujev z odločevalci in kartografske analize konfliktnih območij. Cilj raziskave je priprava predlogov za podporo prostorske integracije sprtih skupnosti in njune poti $k$ spravi.

\section{KLJUČNE BESEDE}

politična geografija, prostorska segregacija, teritorialnost, skupnost ob pregradah, medetnično povezovanje, sprava, Belfast, Severa Irska

The article was submitted for publication on May 7, 2015. 


\section{Introduction}

Spatial segregation is defined as the uneven distribution of predefined social groups within residential spaces and places where they spend time when not at home (Boal 1987; Lysaght and Basten 2003). Segregation in Belfast has been a long-running issue in the city and for many years, has received attention from scholars in the socio-psychological, political, and economic fields (Boal 1969; Doherty and Poole 1995; Murtagh 2002; McNair 2006). This paper aims to analyse how political, social, and economic division shapes the spatial practice. It establishes a historical framework around spatial segregation under which the concept of territorial and ethnic conflict and the determination of identity in Belfast will be discussed.

The unstable nature of the organised colonization ("plantation «) of the island's northern areas by the British Empire from the sixteenth century on is considered to be one of the historical origins of the conflict (Darby 2003). Many of those who arrived during the earliest plantations eventually assimilated into the native Irish population. Those who came to settle the northern parts of the island from Scotland retained both their religious and political differentiation. Throughout the centuries, there have been frequent insurrections and rebellions by the Irish against British rule, which pressured the British government to grant independence to the island (Fitzduff and O'Hagan 2009). As a result of Ireland becoming a sovereign country, Northern Ireland was created by the 1920 Government of Ireland Act after the Irish War of Independence, which granted Ireland independent rule but left six counties in the north as a part of the United Kingdom (UK).

The violent territorial conflict known as the Troubles began in the late 1960s. Over 3,000 people were killed and thousands were left injured. Thus far, only the paramilitary cease-fire of 1994 and the attendant peace process with the signing of the Good Friday Agreement in 1998 have been successful in bringing significant change to the political situation.

High levels of ethnic segregation in everyday life show few signs of diminishing (Lysaght and Basten 2003). The contemporary territorial and ethnic conflict remains at the surface-level and is a struggle between those who wish to see Northern Ireland remain part of the UK and those who wish to see the reunification of the island (Kempny 2013). However, Siobhan McEvoy (2000) argues that it is a conflict that revolves around identity and territory with economic elements. Identity and ethnicity are primarily determined by religious affiliation: the two local main groups in Northern Ireland define themselves nominally as Catholics or Protestants. Moreover, due to complexity of the conflict, it is important to consider the political and national labels as well (Kempny 2013). The Protestant majority in Northern Ireland, identified as unionists, defines itself as British and largely supports the continued incorporation into the UK. In contrast, the Catholic minority, nationalists, identifies itself as Irish and they desire a united Ireland (Archivk 2013).

Territory is identified as either »ours" or »theirs" and arguably derives its definition the most ethnically throughout Northern Ireland in Belfast. Contested space is of an especially high concern at bordering spaces known as interfaces. Every other form of segregation derives from spatial segregation, as people who come from spatially defined interface communities are unlikely to mix. According to a 2012 study, an estimated one third of the respondents living within interface communities in Belfast still feel the presence of workplace and educational segregation (Kumer 2013).

This paper aims to analyse the driving forces for the ethnic spatial segregation in Belfast through a geographical perspective. This perspective has received relatively little attention in the academic community. The paper also provides recommendations to support and promote the reconciliation process for a long-term peaceful cohabitation of the two ethnic communities.

\section{Data and Methods}

The discussion is based on a combination of a literature review and findings from the author's own research conducted in 2012, which included fieldwork, interviews, and cartographic analyses 
(Kumer 2013). During the fieldwork process, numerous spatial boundaries were identified with the aim to produce an accurate map of the territorial dimension of the interface communities. In-depth interviews were conducted with scholars, NGO representatives, and political stakeholders in order to obtain a multi-dimensional view of the conflict. An attitudinal study was also carried out through 42 semi-structured interviews, conducted with members of an interface community. This offers an opportunity to understand people's problems, emotions, fears, needs, and perceptions of segregation and territoriality. Extensive literature was reviewed to apply research findings to the existing knowledge.

\section{Driving forces of spatial segregation}

In order to problematize segregation in Belfast and to prepare a context for the later discussion on the possible solutions for desegregation, we first examine the factors (drivers) that stimulate the continuing spatial segregation within the city. We identified six main drivers of spatial segregation: the political division of society, contested interface areas, poor social-economic structure of the interface area residents, continuous sectarianism and ethnic violence, strong territorial identity, and poor cross-community relations.

\subsection{City's political divide}

Until the late 1960s, when the Catholic community launched a campaign for equal rights, the parliament was dominated by Protestants and saw a systematic social discrimination against the Catholic minorities. The Good Friday Agreement of 1998 set up a power-sharing mechanism, but the agreement was not implemented until 2007 (Northern Ireland Profile 2012). Hopes for a permanent end to the violence have been stifled due to still active dissident paramilitary groups of both Catholic and Protestant communities, often backed by their political wings. In spite of the power-sharing system, Northern Ireland remains sectarian; this is seen by the lack of collaboration between the pro-Catholic and pro-Protestant political parties and their unwillingness to step back from giving into populist sectarian rhetoric. An example of this was the controversial decision of Belfast's City Council policy committee in 2012 to restrict the number of days when the Union Flag should be flown from public buildings (Nagle 2013). This decision was seen as a consequence of the rising majority of the Catholic community in Belfast, which outnumbered Protestants for the first time in history according to the figures from the 2011 census (NISRA 2013).

Furthermore, the local society is still embroiled in controversial talks over the legacy of its troubled past and over issues surrounding contentious parades today. As one respondent noted (see Kumer 2013):

"It's a Catch 22. The Orange Order promotes the right of assembly, which is a democratic right. They say they have a mandate and the right to march. The problem is that "to march « is a much more embedded tradition within the Unionist community than it is within the Republican community. Many of those marches have now been solved or they are better marshalled or they have reduced the scale in terms of violence. The other part of the Catch 22 is the right not to be offended. I think one of the fundamental problems is that it's very difficult when you have two absolute notions, one the right to march and one the right to protest. /.../ But my personal attitude is that you should have the right not to march where you are not welcome. And you should also have the right not to be offended."

\subsection{Interface barriers}

The role of interface barriers in creating two segregated communities can best be described through the series of articles by Boal (1969). Before the rise of the conflict, Boal conducted a research involving a Catholic community from Falls Road and a Protestant community from Shankill. It was the buffer zone 


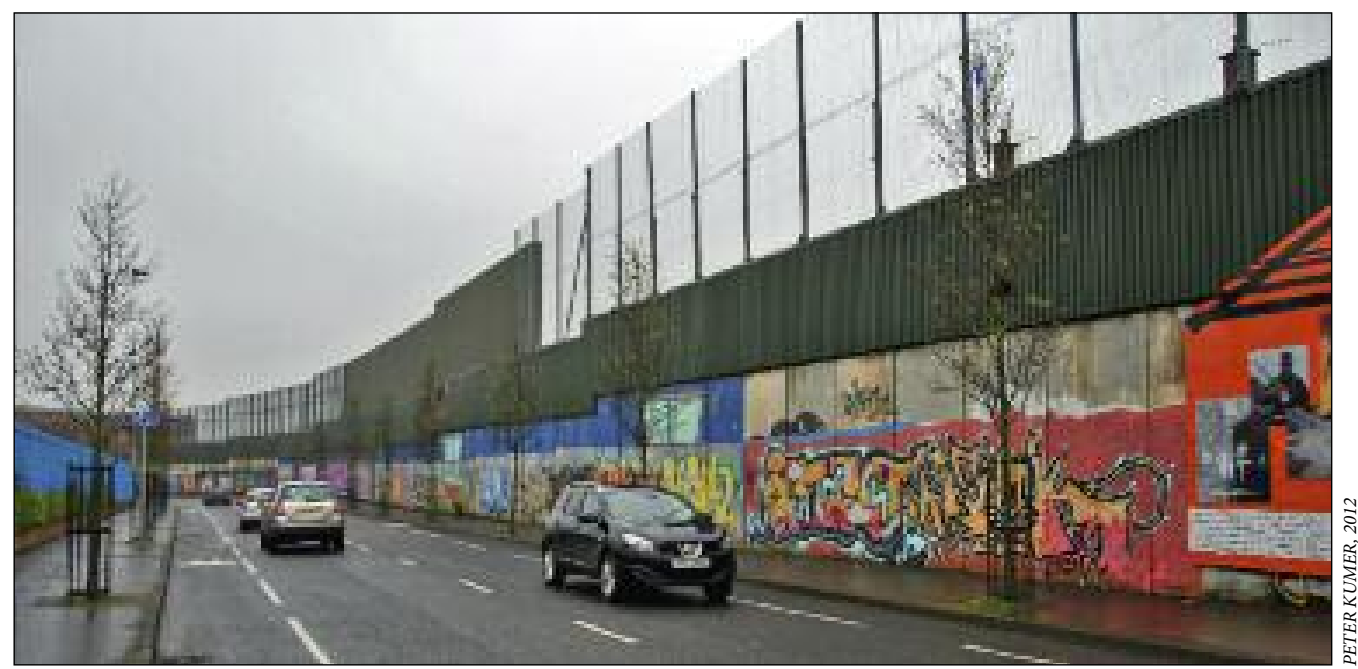

Figure 1: Multilevel interface barrier that runs along Cupar Way and divides Catholic Falls and Protestant Shankill Community.

Table 1: Responses of Belfastians when asked whether they want interface barriers to be removed (Kumer 2013).

NO, maybe no undecided YES, maybe yes

Depends on the area, in our area I don't support this idea.

(Female, 45 years, Newington)
Depends on where you live.

The only time there is trouble is on the Twelfth. Kids throw stones at each other during summer holidays because they have nothing better to do. (Male, 63 years, Newlodge)
It is gonna take a very long time for that to happen. Probably not in my lifetime unless Irishness gets a full equality. Working class people would fight, the middle class would not fight, they have a lot to lose. Prisoners were always working class, they would fight for identity. (Male, 35 years, Falls Road)

\begin{tabular}{lll}
\hline $\begin{array}{l}\text { We should keep them as teenagers } \\
\text { and kids can't get on very well } \\
\text { (female, 32 years, Tiger's Bay) }\end{array}$ & $\begin{array}{l}\text { There are still issues about safety } \\
\text { at times of tensions such as parades. } \\
\text { (Female, 52 years, Ballymacarrett). }\end{array}$ & $\begin{array}{l}\text { I'd love that, but I'm afraid I won't } \\
\text { be able to see that in my lifetime } \\
\text { (I come from a mixed family). } \\
\text { (Female, 41 years, Short Strand) }\end{array}$ \\
\hline $\begin{array}{l}\text { There would be murders if that } \\
\text { happened. (Male, 30 let, city centre) }\end{array}$ & $\begin{array}{l}\text { Gradually ... } \\
\text { (Male, 30, New Lodge) }\end{array}$ & $\begin{array}{l}\text { We should live closer together, } \\
\text { everyone wants to go on with their } \\
\text { lives, you don't want to live in the } \\
\text { past with bombs and shootings } \\
\text { (Male, 45 years, Tiger's Bay) }\end{array}$ \\
& $\begin{array}{l}\text { The presence of interface barriers } \\
\text { makes the people feel the conflict } \\
\text { still as 'real'. This gives a reason for }\end{array}$ \\
& $\begin{array}{l}\text { a lot of groups to get money from the } \\
\text { European Union, which they squander } \\
\text { without really doing anything for us. } \\
\text { (Female, 30 years, Newington) }\end{array}$ \\
&
\end{tabular}


that was dividing the two sites, where 66 per cent of the residents defined themselves as Protestant. Boal discovered two segregated communities (divided by a boundary) with some ethnic mixing. After the outbreak of the conflict in 1976, he conducted a new research in the same area. He realized that the division along the peace lines was much more apparent. Due to the violence and the creation of the interface barrier along Cupar Way, around 60 households decided to move out of the area into their ethnic heartland where they felt safe (Boal 1969; 1976; Doherty and Poole 1995).

After the erection of the first "peace wall« on Cupar Way, interfaces were built throughout Belfast, dividing Catholic and Protestant areas. As argued by Feldman (1991), »urban demarcation increased proportionally with the increase of segregated residential areas« (Feldman 1991, 28).

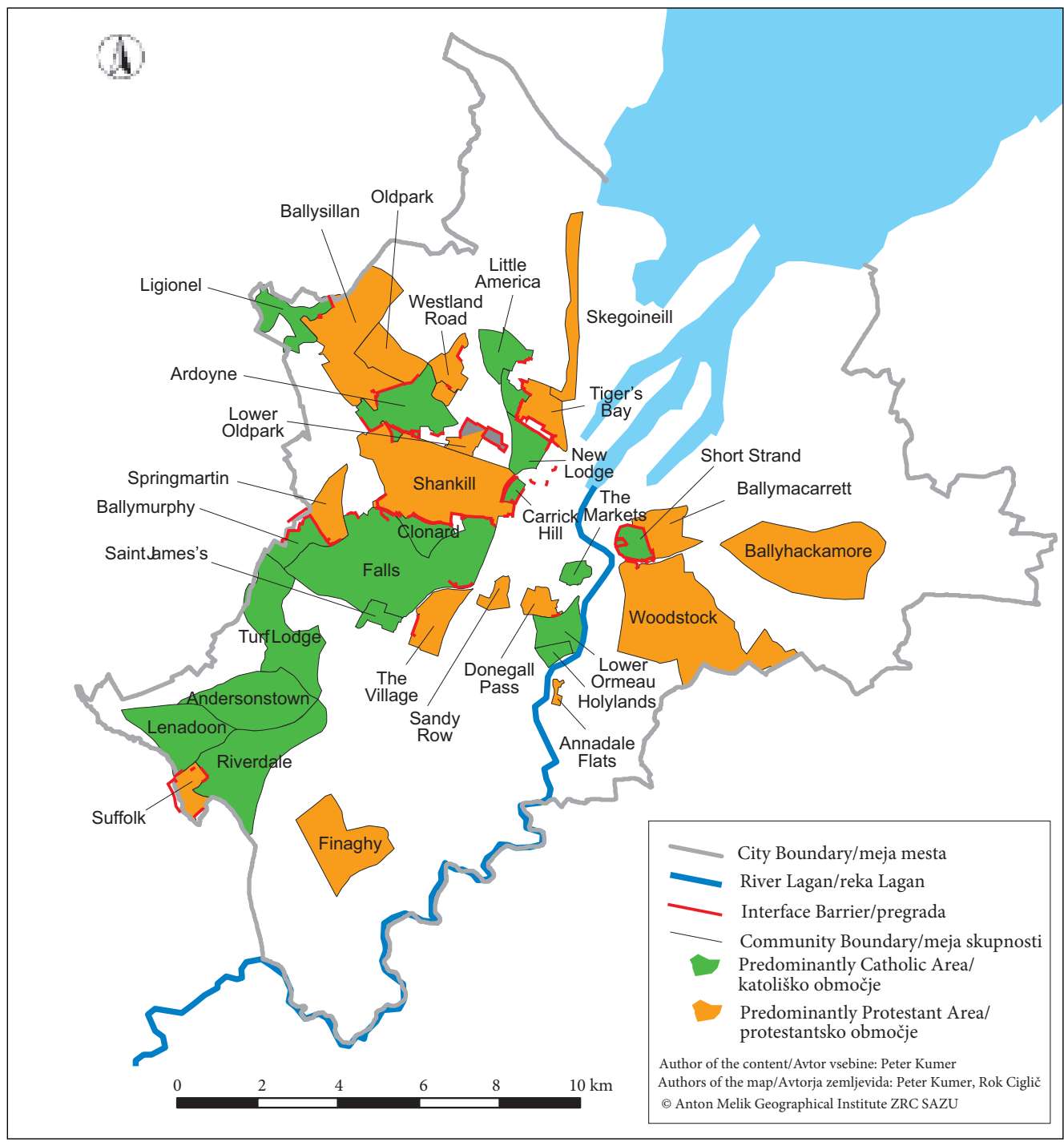

Figure 2: Location of interface communities and barriers within the Belfast urban area (Murtagh 2002; Shirlow and Murtagh 2006; McNair 2006; Murtagh 2002; Plöger 2007; O'Halloran 2012; Kumer 2013). 
The 2012 report by the Belfast Interface Project identifies 99 different security barriers and forms of defensive architecture in residential areas across Belfast. The barriers have been constructed steadily since 1969; one third of them have been built since the 1994 ceasefire. Many have been rebuilt and what is more concerning, different stakeholders are still planning to build new ones (O'Halloran 2012). The reasons why the barriers were initially built, e.g. the feeling of security, protection against violence, reducing tension among communities (Byrne, Heenan, and Robinson 2012) are being replaced by their consequences, such as the feeling of fear due to not knowing the other community and not having any kind of contact with them. Nowadays, people seem to be divided on the opinion of whether to remove the barriers (see Table 1). Identifying their location is one of the crucial factors in the process of locating the segregated communities. Their purpose is to physically prevent personal contacts and territorial extension of the residential neighbourhoods. They were identified through the research of the historical heartlands of each community through existing literature, through research produced by the Belfast Interface Project (O'Halloran 2012), and through field work (see Figure 2). Identifying the exact boundaries of the communities within Belfast is the basis of any other research on spatial segregation in this city. Many past researches on spatial segregation and statistical data collection in Belfast were based upon the areas of electoral wards. The boundaries of these smallest administrative units used primarily for statistics and elections do not necessarily coincide with the boundaries of the actual segregated territories; consequently, such research often shows at least partially deceiving results.

\subsection{Socially deprived interface areas}

Segregation is most pronounced in districts that are working-class in composition. Jones (1956) proposed a framework to examine the relationship between social-economic class and segregation. Generally, the level of segregation is lower if the area is populated with higher class residents. This means that a higher segregation level occurs in the areas with poor social-economic conditions. Hepburn and Collins (1981) conducted a research in the south-western part of Belfast and discovered that a higher social class of the residents means that self-imposed apartheid is less likely to happen. It is also worth noting that in Belfast, the lower the class of a person, the higher the possibility that this person lives in a Catholic community. This relation is also evident from the 2010 data. This could probably be explained by the fact that in general, the Protestant community has lived in better social-economic circumstances than Catholics. A simple cartographic analysis performed by overlaying the maps of the multiple deprivation measure (Northern Ireland Multiple Deprivation Measure 2010) and the segregated interface communities suggests a considerable correlation between the two (Figure 3). The higher the score of the multiple deprivation measure, the more deprived the area is. The values of the score are highest in the segregated areas (Kumer 2013). It is also important to emphasize that in recent years, most politically motivated murders occurred within the interface areas (Shirlow and Murtagh 2006; Melaugh 2012; NINIS 2013). A study of the emotional ties of Belfast residents helps to reveal and understand a predefined group of people's spatial attitudes towards specific neighbourhoods. The approach to measuring these emotional ties in our empirical study (Kumer 2013) was partly based on a more comprehensive and long-term study of topofilia and topophobia in Ljubljana, Slovenia (Krevs 2004). The responses of the specific respondents suggest quite clearly (and stereotypically) that the attractiveness and unattractiveness of the areas within Belfast depend on the residency of the interviewees and their ethnic background. Not surprisingly, the most attractive areas for living identified by Catholics are those inhabited by the Catholic minority and the most attractive neighbourhoods for Protestants are the predominantly Protestant areas. The most unattractive areas for both communities are those inhabited by the »ethnic-others".

\subsection{Sectarianism and ethnic violence}

Thirty years of violence has left a permanent wound in the population of Northern Ireland. The violence has been fostered by the acts of the paramilitary wings of political parties and has spread a great deal of fear among the people. 


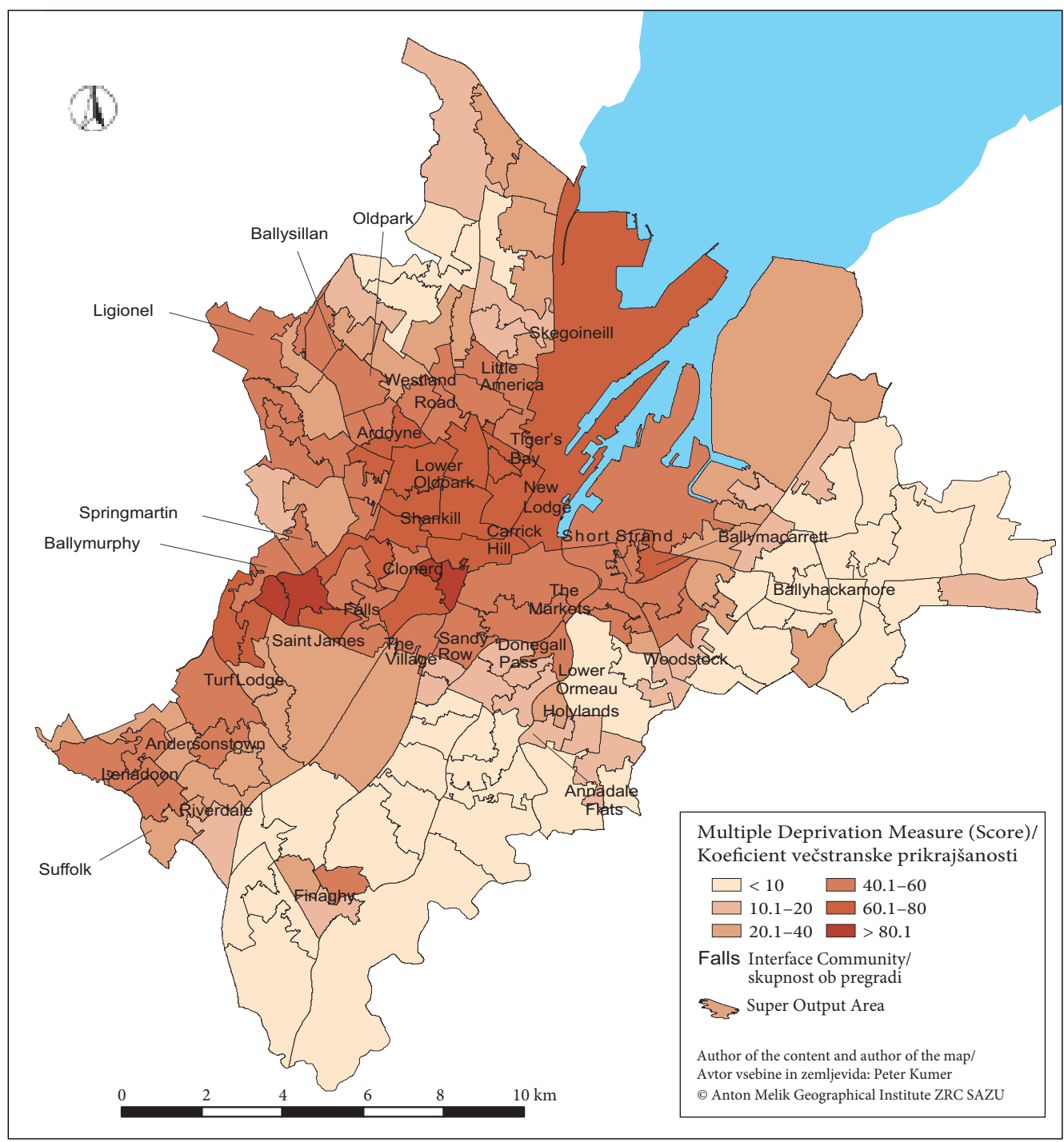

Figure 3: Score of the multiple deprivation measure per super output area for 2010 in Belfast (NIMDM 2010).

Fear of sectarian violence remains a highly significant feature of everyday life for many residents in working-class areas of Belfast. It is mediated by the knowledge that acts of violence continue to be carried out on an almost daily basis, as well as by the residential segregation enforced by territoriality (Lysaght and Basten 2003). A good example of politically motivated crimes that referenced spatial segregation is the »doorstep murder «. The term refers to a political assassination by paramilitary units, which were able to mount rapid incursions into ethnically opposed communities during the Troubles due to the rigidified sectarian residential segregation. They picked residents based on the assumption that the victims' presence in a certain space was a definitive sign of their ethnic and political affiliation. Paramilitaries simply drove up to a household and asked for the resident male. As the victim came to 
open the door, he was assassinated. By indicating which victims were Catholic and which were Protestant, Boal and Murray's Doorstep Murder Map was a great representation of the ethnic spatial segregation (Feldman 1991; Murray and Boal 1979).

\subsection{Territoriality}

Soja (1971) defines human territoriality as a »behavioural phenomenon associated with the organization of space into spheres of influence or clearly demarcated territories which are made distinctive and considered at least partially exclusive by their occupants or definers. " There are many elements in the landscape that differentiate it as belonging either to one side or the other: Catholic or Protestant, Nationalist or Unionist, Republican or Loyalist. Catholic and Protestant parts are often delineated by peace lines (Cairns 2000) and are also often demarcated by flags, painted curb stones, and murals (Kempny 2013). Murals, for example, are a part of the wider culture of both communities. While some people celebrate the paintings and consider them an expression of popular culture, political resistance, or working-class defiance, others consider them to be expressions of power or even acts of intimidation. Despite the controversy they generate, the murals have become popular with the media, which uses them to convey a sense of distinctiveness, place, and authenticity. Tourists in particular see them as a matériel remnant of the conflict, a legacy of the last 30 years (Simone-Charteris and Boyd 2011). Territoriality is also manifested through parades such as the Orangemen parade that take part during marching season every year. The areas that are often subject to territoriality are interface areas, also called single identity zones. They are characterized by a high level of ethnic segregation.

Whether or not a sectarianized space is identified by community emblems and markings, local people possess a complex body of knowledge about these locales and how to behave there (Lysaght and Basten 2003). This has led individuals to organize their own movements and to develop a strategy of spatial mixing and avoidance of the territory of the other.

This is how two respondents from interface areas described their movement across the city: Respondent 1:

"When I want to visit my parents to get to the motorway, I always drive down Shankill, down Peters Hill to go to Westlink. Where I could drive here through the gates and it would take me 2 minutes. Instead I do the 15 minutes detour. Because in my head that is like a no-go area. I know a lot of people who still do that. It's because if you haven't been in that area you are a bit afraid to go there." (Female in her fifties, Shankill)

Respondent 2:

"In Protestant areas you still have the painted curb stones in red, white, and blue. The footpaths, you know. Or even the electricity poles. That's a very Protestant thing. And around the Twelfth you can have an explosion of flags all around the protestant area. If I go to the doctor, I could avoid the Protestant side. I do it all the time but I don't do it in the summer and I do it especially when I really have to go to the doctor because it's quicker. But when I come back, I go the other way. I go up Duncairn Gardens, Antrim Road back to Atlantic Avenue, Newington Avenue, Newington Street." (Female in her thirties, Newlodge)

\subsection{Inter- and cross-community relations}

A lack of friendship ties with the »ethnic-other « is one of the characteristics that defines the relations between the two communities. Whereas the members of one community are very much involved in different projects that connect the residents of one interface area, Darby (1986) argues that the two communities adopted two main behavioural patterns after the time of violent confrontation during the Troubles: avoidance of contact and partial interaction (restricted to clearly defined contexts such as the pursuit of common material interests). 
This is the situation faced on a daily basis, explained by a cross community worker:

"Teenagers from both sides have the opportunity to make friends through the project. But unless they are involved in a youth organisation, they don't have the opportunity. In Falls, there are houses right up against the wall. I've heard a lot of people saying that they have no idea what's on the other side of the wall. They just grow up with the wall and they don't think of what's on the other side, who those people are."

\section{Contribution to the set of possible effective actions in coping with the spatial segregation}

A series of activities dealing with spatial segregation have already been introduced in Belfast. The current policy is mainly focused on the following:

1. Allocation of public apartments to families regardless of their ethnic belonging,

2. Parades Commission efforts, and

3. Police crime and disorder prevention.

These activities have limited the impact of the complex issues stemming from the spatial segregation. Based on the reports on the "alternative « activities and the conducted interviews, we strongly suggest upgrading the set of activities by at least the following:

4. Cross-community schemes,

5. Public and shared space initiatives, and

6. A political reconciliation process.

Ad. 1: The Northern Ireland Housing Executive (NIHE) was established in 1971 in order to deal with the allocation of public housing for working class tenants. 91 per cent of the areas owned by NIHE were populated by segregated communities in 2001 (Shuttleworth and Lloyd 2006). In such a situation, it seems very indicative that 20 out of 36 respondents claim the NIHE should do more to promote ethnically mixed residential areas (Kumer 2013). This shows that general power-sharing seems to have accentuated the segregation rather than reduce it.

Ad. 2: Marching season starts on Easter Monday and lasts until the end of September. Most of the parades are organised by Protestants, but Catholics also organize their own. The parades can become very controversial as they are perceived as an element of territoriality. The parades, especially the ones organized on July 12 each year by the Orange Order, often lead to violence and rioting, but it is impossible to prohibit them. All public authorities must adhere to the standards of the 1998 Human Rights Act that came into force in 2000 and was laid down by the European Convention on Human Rights (Hamilton, Jarman, and Bryan 2001). The Parades commission, an independent quasi-judicial body set up in 1997, was established to place certain conditions on a parade. These involve, for example, the restriction of a parade from a particular area, a route restriction, a restriction on music, or the exclusion of a previously badly behaved group from a parade (Parades Commission 2014). Thanks to the intervention of the commission, the city managed to settle disputes and avoid some of the ethnic clashes and violence, although it remains unrecognized by some of the groups.

Ad. 3: The Police Service of Northern Ireland (PSNI) is often found in the position of being blamed for much of what is occurring in terms of neighbourhood crime and disorder, although their main purpose is to prevent such incidents. Data from a New Lodge (Catholic area in the northern part of the city often characterized by sectarian violence and high levels of crime) study shows that the police is perceived to be unresponsive and disengaged and there is a high level of non-reportage to the police. However, in reality, PSNI is the first body to deal with crime and disorder; in addition, the New Lodge area has a standard level of policing that is common in many urban, working-class areas. Perhaps more importantly 
than increasing the presence of policing in notorious areas around Belfast would be to promote the actual efforts and positive outcomes of PSNI and thus build trust among the residents (Shirlow, Pino Ellison, and 2012).

Ad. 4: Divisions persist not only in the form of the barriers that separate some communities. Preferences in schooling, sport, and culture often follow the same ethnic and religious fault lines. A phenomenon that is evident from the research is the distinctive spatial behaviour of the inhabitants in segregated areas, which indicates a need to avoid the territory of the »others". Shirlow and Murtagh (2006) discovered that 58 per cent of the population of one ethnic community travels at least twice more than necessary to visit a public institution just to avoid the area of the opposite community. According to the results of the structured interview conducted in 2012, around one fifth of the respondents have already experienced troubles while doing different activities that are explained by living in an interface area. Moreover, about one third of the respondents never had any contact with members of the opposite community. Almost a quarter of those asked would never make a journey to the area dominated by the other community. Therefore, it is difficult to bring together young people from both sides to play a football match, perform in a band, or act in a theatre production. However, the hard work of some cross-community schemes is beginning to show some results. Such initiatives appeared at the end of the Irish Civil War and were meant to bring together Protestant and Catholic groups, preferably young people, since they are the ones who engage in most of the violent riots nowadays and to compel them to spend some free time together and make strong connections, take part in interethnic dialogue, and cooperate. The best practices contributed a lot to breaking the stereotypes and to reconciliation. This proved to be a better solution towards reconciliation than building new, longer and taller barriers between communities (Kumer 2013). In spite of the scandals regarding the cross-community schemes that were financed by the EU and were actually promoting single-community initiatives in previous years, there have also been good examples of cross-community work. One such good example is the Cross-Community Outreach Project, a shared project between the Shankill Women's Centre and the Good Relations office from An Culturlann. The idea is to bring people together through the interface. This is how Marion Weir, an officer from the Shankill Womens Centre described her work (interview conducted on April 23 ${ }^{\text {rd }} 2012$ ):

"One of projects we are working on is the Culture Land, because we both try to do community relations work through arts and through culture. We have a steering group made of people from both sides of the interface (Shankill and Falls), Housing Executive, Belfast City Council, Community Workers. We do all kind of arts projects. Some artists were too ambitious, because they wanted to use some of the sights. But you need to get a permit for that. You have to go to the police, to the paramilitaries. So we decided that all we wanted to do is organize a street festival on International Peace Day (21 ${ }^{\text {st }}$ of September) on Townsend Street because nobody really lives there. There are lots of small businesses, so we are hoping to work with them and the ministries and everybody else who's involved. Ask if the gates can be open a bit longer. We will try to bring groups from the Falls and groups from the Shankill and work with the schools. They will prepare some sort of performance. There will hopefully also be a Young Men's choir from St Peters Cathedral, which is known to be the best in Northern Ireland. So we will try to involve as many people as possible."

Ad. 5: There were various initiatives in the 1990s and 2000s to prompt urban regeneration and to "open the city centres to all communities and develop a common civic culture for Belfast (Bryan 2003, 264). This involved attracting global capital and investing in new large-scale projects, which funded complexes such as Castle Court, the Odyssey Centre, and a Hilton Hotel. The initiatives were also aimed at organizing cultural events, such as St. Patrick's Day or the Belfast Carnival, to give Belfast a sense of being a multicultural city. At the same time, there have been attempts to promote inclusive public space, which was linked to putting down Loyalist displays (see Bryan and Stevenson 2009) and encouraging the painting of new murals that would promote cultural diversity. Such an example is the Latin American mural in Ormeau Park (Kempny 2013). 
Using the principles of creative placemaking is one of the possible strategies to create a shared violence-free space in Belfast. It is a strategy that intentionally leverages the power of the arts, culture, and creativity to serve the interest of the community while driving a broader agenda for change, growth, transformation and building a distinct character (Approaches to Creative Placemaking 2013). This could replace the old divisions with a new identity. Its concept is to create a situation in which partners from the local governance, private, non-profit, and community sectors, as well as local residents come together and shape the physical and social character of a neighbourhood around the arts and cultural activities. Besides the improved public safety, creative placemaking in public spaces rejuvenates the structures and streetscapes, improves local businesses viability, and brings together diverse, educated, and creative people. Many good practices of creative placemaking come from North American cities (Markusen and Gadwa 2010b). Similar to the successful Baltimore Arts and Entertainment districts, Belfast developed distinctive cultural zones within the city and named them Cultural Quarters. They are comprised of the Titanic, Cathedral, Queen's, and Gaeltacht Quarter. A cultural district is where cultural activities are clustered together; a well-recognized, labelled, mixed-use area of a city in which a high concentration of cultural facilities serves as the anchor of attraction (Frost-Kumpf 1998; Markusen and Gadwa 2010a). As they host key arts and culture-based organizations, they have a huge potential to become a tourist hotspot (such as Temple Bar in Dublin or Soho in London). With the support of the local governance and local neighbourhoods, it is important to build a shared identity (rather than sectarianism) within the cultural quarters, promote them as open to all ethnicities, and, finally, attract urban planners, architects, and artists to work and develop the area.

Ad. 6: When discussing the history of Northern Ireland, the term peace process is used to describe the events leading up to the 1994 paramilitary ceasefire, the 1998 Good Friday Agreement, and the series of subsequent attempts to achieve an end to the civil conflict and a political settlement for the differences that divide the Catholic and Protestant communities (Melaugh 2006). Despite a much improved security situation in the years since 1998, a full implementation of the Good Friday Agreement has been challenging. In 2007, a power-sharing system was established between the Democratic Unionist Party (DUP) and Sinn Fein. The DUP and Sinn Fein are the largest unionist and nationalist parties, respectively, in Northern Ireland and have long been viewed as the two most polarized forces in Northern Ireland politics. Later, other issues arose between the disputed parties, but they managed to reach an agreement in part due to the diplomatic support of the USA (Archivk 2013). The threat level of the 2012 for terrorist attacks in Northern Ireland was severe, but the general consensus appears to be that if reunification were ever to take place, it would only occur by political means and with the consent of all Irish people (Villiers 2012). In this regard, the political leaders should work seamlessly together to achieve peace.

\section{Conclusion}

The history of dividing and searching for bits of cooperation, construction, and hopefully gradual decomposition of the spatial segregation in Belfast are complex processes characterized by ups and downs. It is our view that the creation of a mixed and violence-free society is the only long-term answer to the challenge of a stable coexistence in Belfast. To support this turbulent process towards reaching such a noble goal, permanent efforts are needed to support a better understanding and re-evaluation of the process and its drivers, as well as to find ways to bring changes into the real life of the city's residents. The paper aims to contribute to these permanent efforts by re-evaluating the knowledge on spatial segregation in Belfast from the literature and interviewing residents and other "players « in this process.

Our study conducted in 2012 (Kumer 2013) identified the following driving forces for ongoing spatial segregation in Belfast: political division, urban demarcation (interface barriers), socially deprived ethnic neighbourhoods, presence of ethnic violence, strong territorial behaviour of the communities, and a lack of their friendship ties. 
The field work data analysis revealed specific habitual patterns of people living within the interface areas. Among the implications of high segregation are the fear of crossing the territory of the »Other", the cost in terms of time, and the cost for having to use the major technique of territorial avoidance.

Different techniques were used to map the interface areas and ethnic boundaries. The identification of the exact boundaries then served as the basis for further research on spatial segregation. The research was particularly focused on in-depth and structural interviews to identify the problems, fears, and needs of the residents living within the interface communities. In its final part, this article emphasizes the existing efforts to promote inclusive residential and public space. Cross-community schemes, public and shared space initiatives, and the political efforts in the peace process need to be implemented together with the already existing tools (public apartment allocation, efforts of the Parades Commission and the Police) creating a safe, violence free, but ethnically diverse society.

\section{References}

Archivk, K. 2013: Northern Ireland. The Peace Process. Congressional Research Service, Report for Congress. Internet: http://www.fas.org/sgp/crs/row/RS21333.pdf (12.1.2014).

Approaches to Creative Placemaking, 2013. Internet: http://www.artscapediy.org/Creative-Placemaking/ Approaches-to-Creative-Placemaking.aspx (12.1.2014).

Boal, F. W. 1969: Territoriality on the Shankill-Falls Divide, Belfast. Irish Geography 6-1. Dublin. DOI: http://dx.doi.org/10.1080/00750776909555645

Boal, F. W. 1976: Ethnic residential segregation. Social Areas in Cities I: Spatial Processes and Form. London.

Boal, F. W. 1987: Segregation. Social Geography, Progress and Prospect. London.

Bryan, D. 2003: Belfast. Urban space, "policing « and sectarian polarization. Wounded Cities. Destruction and Reconstruction in a Globalized World. Oxford. DOI: http://dx.doi.org/10.5040/9781474215985.ch-012

Bryan, D., Stevenson, C. 2009: Flagging peace. Struggles over symbolic landscape in the new Northern Ireland. Culture and belonging in divided Societies. Contestation and Symbolic Landscapes. Philadelphia.

Byrne, J. Heenan, C. G., Robinson, G. 2012: Attitudes to Peace Walls. Research Report to Office of First Minister and Deputy First Minister. Belfast.

Cairns, D. 2000: The object of sectarianism: The material reality of sectarianism in Ulster Loyalism. Journal of the Royal Anthropological Institute 6-3. Cambridge. DOI: http://dx.doi.org/10.1111/1467-9655.00025

Darby, J. 1986: Intimidation and the Control of Conflict in Northern Ireland. Dublin.

Darby, J. 2003: Northern Ireland: The background to the Peace Process. CAIN. Internet: http://cain.ulst.ac.uk/ events/peace/darby03.htm (1.3.2015).

Doherty, P., Poole, M. A. 1995: Ethnic Residential Segregation in Belfast. Coleraine.

Feldman, A. 1991: Formations of violence. The Narrative of the Body and Political Terror in Northern Ireland. Chicago.

Fitzduff, M., O'Hagan, L. 2009: The Northern Ireland Troubles. INCORE background paper. CAIN. Internet: http://cain.ulst.ac.uk/othelem/incorepaper09.htm (12.1.2014).

Frost-Kumpf, H. A. 1998: Cultural districts. The Arts as a Strategy for Revitalizing our Cities Americans for the Arts. Springfield.

Hamilton, M., Jarman, N., Bryan, D. 2001: Parades, protests and policing. A Human Rights Framework. Belfast.

Hepburn, A. C., Collins, B. 1981: Industrial society. The structure of Belfast, 1901. Plantation to Partition. Belfast.

Jones, E. 1956: The Distribution and segregation of Roman Catholics in Belfast. Sociological Review 4-2. Malden. DOI: http://dx.doi.org/10.1111/j.1467-954x.1911.tb02131.x 
Kempny, M. 2013: Tales from the borderlands. Polish migrants' representations of the Northern Irish conflict in Belfast. Space and Culture 16-4. Thousand Oaks. DOI: http://dx.doi.org/10.1177/ 1206331212452818

Krevs, M. 2004: Perceptual spatial differentiation of Ljubljana. Dela 21. Ljubljana. DOI: http://dx.doi.org/ 10.4312/dela.21.32.371-379

Kumer, P. 2013: Socialno-geografske posledice prostorske segregacije v Belfastu (Socio-geographic effects of the spatial segregation in Belfast). B. Sc. Thesis, Faculty of Arts, University of Ljubljana. Ljubljana.

Lysaght, K., Basten, A. 2003: Violence, fear and the everyday: Negotiating spatial practices in the city of Belfast. The Meaning of Violence. London.

Markusen, A., Gadwa, A. 2010a: Arts and culture in urban or regional planning: A review and research agenda. Journal of Planning Education and Research 29-3. Thousand Oaks. DOI: http://dx.doi.org/ $10.1177 / 0739456 \times 09354380$

Markusen, A., Gadwa, A. 2010b: Creative Placemaking. Washington.

McEvoy, S. 2000: Communities and peace: Catholic youth in Northern Ireland. Journal of Peace Research 37-1. London. DOI: http://dx.doi.org/10.1177/0022343300037001005

McNair, D. A. 2006: Social and Spatial Segregation: Ethno-National Separation and Mixing. Ph. D. Thesis. Queen's University of Belfast. Belfast.

Melaugh, M. 2006: The Irish Peace Process: Summary. CAIN. Internet: http://cain.ulst.ac.uk/events/ peace/sum.htm (12.1.2014).

Melaugh, M. 2012: Draft List of Death Related to the Conflict from 2002 to the Present. CAIN. Internet: http://cain.ulst.ac.uk/issues/violence/deathsfrom2002draft.htm (12.1.2014).

Murray, R. Boal, F. W. 1979: The Social Ecology of Urban Violence. Social Problems and the City: Geographical Perspectives. Oxford.

Murtagh, B. 2002: The Politics of Territory. Wiltshire. DOI: http://dx.doi.org/10.1057/9781403920133

Nagle, J. 2013: Nationalism in the news. Blowing the wind: The politics of recognition and the Belfast flag conflict. The Ruritarian for ASEAN 2013 2-3. Belfast.

NIMDM - Northern Ireland Multiple Deprivation Measure, 2010. Internet: http://www.nisra.gov.uk/ deprivation/archive/Updateof2005Measures/NIMDM_2010_Report.pdf (1.2.2013).

NINIS - Northern Ireland Neighbourhood Information Service, 2013. Internet: http://www.ninis2.nisra.gov.uk/public/Home.aspx (1.2.2013).

NISRA - Northern Ireland Statistics and Research Agency, 2013. Internet: http://www.nisra.gov.uk/ (28. 1.2013).

Northern Ireland Profile. BBC Online, 2012. Internet: http://news.bbc.co.uk/2/hi/europe/country_ profiles/4172307.stm (12.1.2014).

O'Halloran, C. 2012: Belfast interfaces. Security Barriers and Defensive Use of Space. Belfast.

Parades Commission. FAQ, 2014. Internet: http://www.paradescommission.org/frequently-asked-questions/ (12. 1.2014).

Plöger, J. 2007: Belfast City Report. Centre for Analysis of Social Exclusion. London.

Shirlow, P., Pino, N. W., Ellison, G. 2012: Assessing the determinants of public confidence in the police: A case study of a post-conflict community in Northern Ireland. Criminology and Criminal Justice 13-5. London. DOI: http://dx.doi.org/10.1177/1748895812462597

Shirlow, P., Murtagh, B. 2006: Belfast. Segregation, Violence and the City. London.

Shuttleworth, I., Lloyd, C. 2006: Mapping Segregation in Northern Ireland. Belfast.

Simone-Charteris, M., Boyd, S. W. 2011: The potential for Northern Ireland to promote politico-religious tourism: An industry perspective. Journal of Hospitality Marketing and Management 20, 3-4. Philadelphia. DOI: http://dx.doi.org/10.1080/19368623.2011.562438

Soja, E. W. 1971: The political organization of space. Resource Paper 8. Washington.

Villiers, T. 2012: Northern Ireland Peace Process. Internet: http://www.politics.co.uk/reference/ northern-ireland-peace-process (1.1.2015). 


\section{Povzetek: Razumevanje posledic prostorske segregacije v Belfastu na Severnem Irskem}

Prostorska segregacija je neenakomerna porazdelitev določenih družbenih skupin v njihovem bivalnem okolju in območju, kjer preživljajo čas, ko niso doma (Boal 1987; Lysaght in Basten 2003). Segregacija med katoliško in protestantsko skupnostjo (etnična segregacija) v Belfastu predstavlja dolgo trajajočo težavo in je že mnogo let $\mathrm{v}$ središču pozornosti raziskovalcev s socialnopsihološkega, politološkega in ekonomskega področja, pri čemer je geografski vidik pogosto zapostavljen. Namen prispevka je ugotoviti, kako politična, družbena in gospodarska razdeljenost vplivajo na družbene odnose v prostoru. Cilj je priprava predlogov, ki bi podprli prostorsko integracijo katoliške in protestantske skupnosti ter njuno pot k spravi.

V raziskavi smo uporabili kombinacijo pregleda literature ter empiričnega dela, ki je vključeval terensko delo, intervjuje in kartografsko analizo. S terenskim delom smo določili lokacije pregrad in druge vrste mejne infrastrukture ter prostorsko zamejili etnične skupnosti. Izvedli smo poglobljene intervjuje $\mathrm{z}$ raziskovalci, predstavniki nevladnih organizacij in političnimi odločevalci ter s tem pridobili uravnotežen pogled na konflikt. Polstrukturirane intervjuje smo izvedli z izbranim vzorcem pripadnikov obeh skupnosti. Služili so za razumevanje posameznikovih težav, čustev, strahov in potreb, povezanih s konfliktom, ter njihovega dojemanja segregacije in teritorialnosti. Soja (1971) definira teritorialnost kot način obnašanja $\mathrm{v}$ prostoru, ki je natančno razločen in demarkiran. $\mathrm{V}$ tem prostoru se njegovi posestniki vsaj deloma obnašajo izključevalno.

Prepoznali smo šest dejavnikov (gonilnih sil), ki spodbujajo prostorsko segregacijo v mestu in se nenehno prepletajo:

1. Globok družbeni in politični razkol, ki ga je poglobilo tri desetletja dolgo krvavo obdobje, poznano kot »the Troubles« (»Obdobje težav«). Od leta 2007, ko sta stopili v veljavo devolucija in diarhija, se je pojavnost nasilnih obračunavanj sicer zmanjšala, a je sektaško obnašanje med politiki še vedno prisotno.

2. Ločevalne pregrade. Ker preprečujejo fizične stike med ljudmi v prostoru, še dodatno prispevajo k tvorjenju stereotipov in sovraštvu med segregiranimi skupnostmi.

3. Socialna prikrajšanost pripadnikov segregiranih skupnosti. S prekrivanjem prostorskih slojev večstranske prikrajšanosti in segregiranih skupnosti smo ugotovili, da so območja segregiranih skupnosti tudi najrevnejša v mestu. To še dodatno prispeva k nastajanju napetosti med njimi.

4. Sektaško in etnično nasilje. Strah pred tovrstnim nasiljem je značilnost vsakodnevnega življenja številnih Belfastčanov. Spodbuja ga prostorska segregacija, ki je posledica teritorialnosti.

5. Teritorialnost. Prepoznali smo specifične vzorce gibanja na konfliktnem ozemlju. Izključujoči prostorski vzorci obnašanja v ljudi vlivajo strah pred prečkanjem »tujega območja in še dodatno spodbujajo segregacijo. To otežuje življenja prebivalcev, ki so razvili tehnike ogibanja zaradi česar za potovanje porabijo več časa.

6. Pomanjkanje družbenih stikov med skupnostma. Medtem, ko so pripadniki ene skupnosti znotraj močno povezani, se skupnosti izogibata medsebojnim stikom, primeri skupnih družabnih aktivnosti so redki.

Da bi skupnosti tesneje povezala, se je politika $v$ preteklosti osredotočala predvsem na naslednje ukrepe: dodeljevanje javno financiranih stanovanj socialno šibkejšim ne glede na njihovo etnično poreklo, restriktivno delovanje Komisije za javne shode (neodvisni državni organ Severne Irske, ki pozorno spremlja javne shode in odloča o pravilih njihove izvedbe) ter prizadevanja policije za zmanjšanje kriminala in nemirov. Ti ukrepi so prispevali k zmanjšanju napetosti. Izsledki raziskave kažejo, da bi politika za dosego "povezovalnega prostora «lahko sprejela (vsaj) še naslednje tri ukrepe:

1. Spodbujanje društvenih dejavnosti, ki povezujejo skupnosti. Meje ostajajo ne le v prostoru, temveč tudi v glavah ljudi, zato so dobre prakse pri povezovanju skupnosti (na primer na področju izobraževanja, športa ali kulture) obrodile že veliko sadov; pomagale so k podiranju stereotipov in ustvarile prijateljske vezi med skupnostma. 
2. Podpora iniciativam, ki stremijo k oblikovanju javnega in skupnega prostora. Eno izmed načel, ki bi lahko prispevalo k oblikovanju nove, povezovalne identitete v prostoru, je načelo kreativnega ustvarjanja prostora (angleško creative placemaking). Poudarja vlogo kulture in povezovanje lokalnih voditeljev, privatnega in neprofitnega sektorja ter lokalne skupnosti.

3. Politična pripravljenost na spravo. Po krvavem, tri desetletja trajajočem konfliktu sta bila razglasitev vojaškega premirja leta 1994 in podpis Velikonočnega sporazuma leta 1998 dosežena s strinjanjem in popuščanjem na obeh straneh. Zgolj široko politično soglasje bo premagalo premostiti še preostale ovire na poti k popolnemu miru.

Prizadevanje za sodelovanje po obdobjih krvavih konfliktov in segregacije je zapleten in dolgotrajen proces. Prispevek poudarja pomen podpore etnično raznoliki in nenasilni družbi za dosego trajnega miru ter sodelovanja med skupnostma v Belfastu. Članek prispeva k tem prizadevanjem s sintezo obstoječega znanja o prostorski segregaciji ter s pridobivanjem mnenj prebivalcev segregiranih skupnosti in drugih deležnikov v tem procesu. Prepoznavanje mej v prostoru in mej teritorialnega obsega posamezne skupnosti je pomemben prispevek k razumevanju prostorske segregacije v Belfastu in izhodišče za nadaljnje raziskave. 
